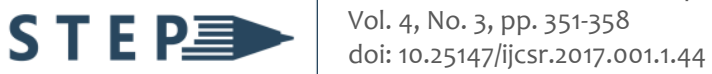 \\ https://stepacademic.net
}

\section{Short Paper \\ Coding Agricultural Education for Innovative Information and Communication Technology in Colleges of Education in Benue and Nasarawa States, Nigeria}

\author{
Garba Emmanuel Ekele \\ Department of Agricultural Education, Federal University of Agriculture, Makurdi, Benue \\ State, NIGERIA
}

Date received: June 11, 2020

Date received in revised form: June 23, 2020

Date accepted: June 25, 2020

Recommended citation:

Ekele, G. E. (2020). Coding agricultural education for innovative information and communication technology in colleges of education in Benue and Nasarawa States, Nigeria. International Journal of Computing Sciences Research, 4(3), 351-358. doi: 10.25147/ijcsr.2017.001.1.44

\begin{abstract}
Purpose - The study investigated coding agricultural education for innovative information and communication technology in Colleges of Education in Benue and Nasarawa States Nigeria.

Method - The study employed a descriptive survey design. Three research questions were formulated to guide the study. The population of the study was 51 lecturers from the Colleges of Education in the study area. There was no sampling as all the populations were used as respondents. The instrument used for data collection was a 22 items questionnaire developed from literature reviewed titled "CAEITQ" (Coding Agricultural Education for Innovative ICT questionnaire). The Cronbach Alpha method of reliability was used to determine the internal consistency of the instrument and a reliability coefficient of 0.77 was obtained.
\end{abstract}

Results - Findings from the study revealed that respondents required all the items on digital design and data visualization, digital programming and coding analysis and digital product management skills in coding agricultural education for innovative ICT in Colleges of Education. 
Conclusion - It was concluded that coding agricultural education for innovative ICT is the most potent weapon for paradigm shift from the traditional method of teaching and learning by both lecturers and students.

Recommendations - It was recommended amongst others that lecturers of Agricultural Education in the various Colleges of Education be trained in digital programming and coding analysis in agricultural education for effective teaching and learning.

Research Implications - The implication of this study is that utilization of digital coding, design, visualization, and programming skills in agricultural education will enhance effective teaching by lecturers in the area of study.

Keywords - coding, agricultural education, ICT, colleges of education

\section{INTRODUCTION}

Information and communication technology have impacted on teaching and learning in agricultural education in several ways. ICT are electronic technologies used for accessing, processing, gathering and presenting information in the field of education. Yusuf (2007) reported that it encompasses software, hardware and connectivity tools used in education. Similarly, Olokun (2007) averred that the use of ICT in education can accelerate, enrich and concretize skills in coding new innovation in agricultural education. Nwana (2010) observed that the growing recognition of ICT as a major contributor to the activities of students and teachers in education has reached a noticeable level-including coding for innovation. Code innovation boosts technology in agriculture. Students and teachers will understand how to control technology with coding. In this way, they can become active, an active part in the digital transformation. Coding in this study is the process of using a programming language in agricultural activities to get a computer to give us the output desired. Each code of agricultural nomenclature carries out a specific task or job. In this way, coding as a computer language can be used for developing a website or software for agriculture. Coding agricultural education, in the context of this study, refers to the use of codes in various fields or activities of agricultural education involving crop production, agricultural product marketing and agricultural product management skills. Code innovation in agricultural education is the ability of the lecturers in colleges of education in the study area to create a specific code in a specific field of agriculture that could simplify implementation of modular task in order to enhance output and productivity in agriculture. The interactions of these concepts points to available arrays of coding skills for agricultural education. Coding turns ideas into reality. In the digital age, every idea for a new solution passes through the realization of a user interface or a software. Coding is thus a powerful educational tool which only required the science of programming, designing and installing a program into a system and which can be accessed and processed for output (UNESCO, 2009). 
Federal Republic of Nigeria (2013) stipulated that science and technology should form the basis for national development and as a tool for influencing the thinking of young children of school age. On the basis of this, students of secondary and tertiary institutions are encouraged to acquire specific skills that will reposition all sectors of the economy. In the context of this study, scientific knowledge with emphasis on coding innovation in agricultural education implies the coding of programme that would enhance teaching that incorporates emerging technologies in planning and execution of lesson delivery. Consequently, curricular offering in agricultural education evolve innovative ways of promoting knowledge with the use of digital skills.

As explained by Surajo and Rislan (2013), effective teaching and learning occurs when trained ICT teachers instruct learners through a well-structured and organized setting within the school system that employs full digital skills. The school system in this case should have digital equipment to accomplish the learning process. Cornell University (2019) re-affirmed that digital or literacy in ICT is the ability to find, evaluate, utilize, share and create content using information technologies and the internet. Digital skills are any skills related to being digitally literate. They include ability to coding a website such as: answer your e-mails, access a company's file on Google drive and ability to tweak a websites code. In developed countries, digital skills are taught and treated with some importance as numeracy and literacy. It is not simply the development of old jobs that make digital skills so important in the modern workplace and educational institutions, but the creation of a digital economy versus the amount of people who are trained to work in it or use it to teach agricultural education.

Agricultural education as explained by Ekele (2019) is a form of systematic instruction at the post-secondary school for the purpose of preparing people for entry into agricultural occupations, job creation, entrepreneurship and agricultural literacy. However, this will be accomplished with the incorporation of ICT in teaching-learning process which improves quality of instruction. ICT plays vital role in agricultural education as being taught in College of Education in the study area. The contribution of ICT in the coding of agricultural education according to Onasanya et al. (2011) will include the promotion of students' commitment to learning, enhances easy delivery of instruction by teachers of agriculture, introduce concepts of new learning of on-line, promotes the process of learning through interaction with simulation, fosters students interest and motivation and facilitates distance digital learning.

Teachers of agriculture are indispensable in the success of instructional delivery with ICT and their competency level in the utilization of ICT tools is crucial to the success of coding agricultural education in colleges of education. The study by Omoniyi and Onadric (2013) on perceived competence of Nigerian school teachers in the use of ICT for teaching and learning sciences revealed that most science teachers do not have the required competence in ICT and that teachers' competence in the use of ICT is not influenced by their teaching experience. Corroborating these findings, Ekele (2019) asserts that 
teachers of agriculture are expected to progressively familiarize themselves from being just presenters of knowledge to knowledgeable facilitators of ICT based classroom and school forum environment. Investigation by the researcher in the colleges of education in the study area revealed that students of agricultural education receive their lesson in a conventional classroom devoid of ICT facilities. Students are also seen without ICT tools. It becomes necessary therefore to investigate coding agricultural education for innovative ICT in Colleges of Education in North Central Nigeria. Specifically, the study determines the following: 1) digital design and data visualization in crop and animal production, 2) digital programming and coding analysis for agricultural product marketing, and 3) digital product management skills.

\section{METHODS}

Three research questions were used in the study. The study adopted the descriptive survey design. The study was carried out in North Central States of Nasarawa, Benue and Taraba States of Nigeria. The population of the study consists of 51 lecturers made up of 17 lecturers from College of Education, Katsina-Ala, 19 from College of Education Oju Benue State, and 15 from College of Education Akwanga, Nasarawa State. There was no sampling as all the population was used for study. A 22-item questionnaire on coding agricultural education for innovative ICT in Colleges of Education titled "CAEICT" was developed from literature and used for data collection. Digital design in agricultural education is a digital format on website. It is a process of mapping out the look and feel of the content that people view and interact with on a computer, tablet or phone screen. Digital visualization involves producing images that communicate relationships among the represented data to viewers of the images. It is use of a systematic mapping between graphic marks and data values as one creates visualization. Digital programming involves skills to create work. It creates computer software and application to specific field which assists in problem solving, logic and critical thinking. Digital product marketing uses digital technologies on the internet to display advertising. It means digital marketing on line.

The instrument has a 4- point response scale of Highly Required (HR), Required (R), Slightly Required (SR) and Not Required (NR) with a corresponding value of 4, 3, 2 and 1, respectively. The instrument was subjected to face validity by three expects, two from the Department of Computer Science and one from the Department of Agricultural Education all from the University of Agriculture, Makurdi. Cronbach Alpha method was used to determine the internal consistency of the instrument. A reliability coefficient of 0.77 was obtained. Two research assistants were involved and were trained on how to administer the questionnaire to the respondents. Fifty-one (51) copies of the questionnaire were administered to the respondents, retrieved and analyzed using mean and standard deviation to answer the research question. Real Limit of numbers were used as benchmark for decision making as follows: 0.5-1.49 (Not required), 1.50-2.49 (Slightly required); 2.50-3.49 (Required); 3.5-4.00 (Highly required). 


\section{RESULTS}

Data presented in Table 1 showed that all the items had mean values that ranged from 2.60 to 3.52 . This indicates that all the items were rated required by lecturers on digital design and data visualization for coding in crop production. The SD (standard deviation) ranges from 0.59 to 1.04 which revealed the closeness of the respondents' opinion with one another.

Table 1. Mean and standard Deviation of Lecturers on digital design and data visualization for coding in crop production $\mathrm{N}=51$

\begin{tabular}{|c|c|c|c|c|}
\hline $\mathbf{S} / \mathbf{N}$ & Items & $\overline{\boldsymbol{x}}$ & SD & Remark \\
\hline 1. & $\begin{array}{l}\text { Ability to use digital design in bright space platform } \\
\text { for on- line learning opportunities in crop } \\
\text { production. }\end{array}$ & 2.82 & 1.02 & Required \\
\hline 2. & $\begin{array}{l}\text { Ability to use Wi-Fi hotspot to download course } \\
\text { work in agricultural education. }\end{array}$ & 2.84 & 0.67 & Required \\
\hline 3. & $\begin{array}{l}\text { Capacity to make use of artificial intelligence to } \\
\text { evaluate the speed at which each student learns. }\end{array}$ & 2.60 & 1.04 & Required \\
\hline 4. & $\begin{array}{l}\text { Use of electronic filed record (EFR) as a digital } \\
\text { representation of a field (soil). }\end{array}$ & 3.60 & 0.80 & Required \\
\hline 5. & Creating imagery data for weather data. & 3.52 & 0.59 & Required \\
\hline 6. & $\begin{array}{l}\text { Use of unified dashboard to see and monitor data } \\
\text { as alerts is received on critical elements like } \\
\text { weather that could affect crop. }\end{array}$ & 2.75 & 0.72 & Required \\
\hline 7. & $\begin{array}{l}\text { Capacity to use automated design system that had } \\
\text { little or no direct human control. }\end{array}$ & 2.58 & 0.70 & Required \\
\hline 8. & $\begin{array}{l}\text { Ability to use artificial intelligence in visual } \\
\text { recognition to identify crop diseases or pest } \\
\text { infestation. }\end{array}$ & 3.16 & 0.94 & Required \\
\hline 9. & Utilization of database on school farm & 2.86 & 0.65 & Required \\
\hline
\end{tabular}

Data presented in Table 2 revealed that all the items had mean values which ranged from 2.82 to 3.36 . This shows that respondents rated all the items on digital programming and coding analysis for agricultural product marketing required. This revelation is given credence from the result of standard deviation of the items which ranged from .61to .93, an indication of closeness in the response of lecturers.

Data presented in Tablez revealed that all the five (5) items on digital product management skills had mean values ranging from 2.77 to 3.09 . This indicates that lecturers rates all the items required. SD of the items ranged from 0.58 to 95 indicating closeness of the responses of respondents to one another. 
Table 2. Mean and standard Deviation of Lecturers in digital programming and coding analysis for agricultural product marketing $(\mathrm{N}=51)$

\begin{tabular}{lllll} 
S/N & Items & $\overline{\boldsymbol{x}}$ & SD & Remark \\
\cline { 2 - 4 } 1. & $\begin{array}{l}\text { Identify the data used for agricultural product } \\
\text { marketing. }\end{array}$ & 3.16 & .72 & Required \\
2. & $\begin{array}{l}\text { Organize stored data in year, type of crop products, } \\
\text { farm and field analysis. }\end{array}$ & 3.14 & .61 & Required \\
3. & $\begin{array}{l}\text { Ability to store an original copy of data on and off } \\
\text { the farm. }\end{array}$ & 2.82 & .76 & Required \\
4. & $\begin{array}{l}\text { Ensure easy access to data in any location of the } \\
\text { farm. }\end{array}$ & 3.36 & .71 & Required \\
5. $\quad \begin{array}{l}\text { Update off-line information and connection re- } \\
\text { established. }\end{array}$ & 2.90 & .84 & Required \\
6. $\quad \begin{array}{l}\text { Collect complete and quality data in related } \\
\text { agriculture field or school farm to ensure execution } \\
\text { of desired analysis. }\end{array}$ & 3.10 & .93 & Required \\
7. Protect data with secured passwords. & 3.17 & .74 & Required \\
8. Define a strategy for sharing files. & 3.00 & .68 & Required \\
\hline
\end{tabular}

Table 3. Mean and Standard Deviation of Lecturers in digital product management skills $(\mathrm{N}=51)$

\begin{tabular}{|c|c|c|c|c|}
\hline $\mathrm{S} / \mathrm{N}$ & Items & $\overline{\boldsymbol{x}}$ & SD & Remark \\
\hline 1. & $\begin{array}{l}\text { Ability to successfully introduce and manage digital } \\
\text { products in agriculture. }\end{array}$ & 2.80 & .58 & Agreed \\
\hline 2. & Implement agile product development & 3.02 & .67 & Agreed \\
\hline 3. & $\begin{array}{l}\text { Address real business challenges in agricultural } \\
\text { business. }\end{array}$ & 2.84 & .74 & Agreed \\
\hline 4. & Harness the fundament of digital innovation. & 3.09 & .95 & Agreed \\
\hline 5. & Ability in creative and user centered design skills. & 2.77 & .58 & Agreed \\
\hline
\end{tabular}

\section{DISCUSSION OF RESULTS}

Findings from Table 1 that lectures rated all the items on digital design and data visualization for coding in crop production required was in consonance with the findings of Adeyemo (2010). He reiterates that lecturers' ability to use digital design, Wi-Fi and bright space platform for on-line teaching and learning is indispensable. Similarly, study by Adomi (2006) corroborates findings from Table 1 particularly the use of electronic field record (EFR) as a digital representation of field or soil. Findings from Table 1 was also in agreement with the findings of Charles (2012) who reported that update off line information and collection of complete data is vital to ensure execution of desired analysis on the modules to be taught. The findings from Table 2 that all the items on 
digital programming and coding analysis were rated required was in agreement with the findings of Okeyefi and Nzewi (2012).They found out that organization of stored data, accessibility to same and execution of field and farm analysis are skills for strategic coding for agricultural product marketing. Similarly, the findings from Table 2 was in line with study by Ejimaji and Obilor (2011) which affirmed the necessity of updating off line information, re-establishing connection and storing original copy of data from field analysis. The findings on digital product management skills was in consonance with the findings of Teo (2008) and lji (2006).They confirmed that implementing agile product developments creativity in user-centered design and managing digital product are integral skills required in digital product management.

\section{CONCLUSION}

The time is ripe for integrating coding in agricultural education for innovative ICT in colleges of education in Nigeria. Studies have been undertaken on more general aspects of the effects of ICT on teaching of science and other related subjects. Advances in technology had lead to the development of CD-ROMs for science lessons. This could also be replicated in agricultural education with coding to allow students conduct advance practical work. ICT utilization in the area of agricultural education will be a pointer to the efficacy of internet technology and as formidable information super high way. Coding information supersedes conventional methods of gathering science resources. However, skills are required for internet users because internet system offers better opportunity for learners and teachers for understanding complex connection in the specific area of agricultural education. Suffices to say that ICT used for teaching and learning is a functional way of providing innovative science and learning, there are ample evidences that had established the potency of coding specific subject or area of specialization for high performance among learners. Lecturers are therefore indispensable for the success of coding agricultural education for innovative ICT. This success is further anchored on lecturers' competence in the use and application of ICT tools for implementing the coding of agricultural education.

\section{RECOMMENDATIONS}

The Ministry of Science and Technology should purchase more ICT tools and equipment that could be used for digital design and data visualization in agricultural education. This will lead to lecturers acquiring early field experience in these areas as they relate to agricultural education. Lecturers and students of College of Education in study area should be trained in digital programming and coding analysis in agricultural education for effective teaching and learning. The experiences gained from constant training will enable the lecturers to fully implement contents of digital design, data visualization and digital product management skills.

The Ministry of Education should engage the services of ICT consulting companies to organize workshop for lecturers and students of college of education in digital product 
management skills. This will entail specific skills in the use of technology in agricultural education such as agricultural robotics, use of agrochemicals that aids in reduction of crop loss on the field as well as storage facilities for crop produce after harvest. Mastery of these skills improves effectiveness in production and prevents spoilage.

\section{REFERENCES}

Adeyemo, S.A. (2010). The impact of Information and Communication Technology (ICT) on teaching and learning of physics. International Journal of Educational Research and Technology,1(2), 48-59.

Adomi, E. E. (2006). Mobile phone usage patterns of library and information science students at Delta State University, Abraka. Electronic Journal of Academic and Special Librarianship, 7(1), 35-39.

Charles, B. A. (2012). An explanation of Teachers skills, perceptions and practices of ICT in teaching and in the Ghanaian Second Cycle Schools. Contemporary Educational Technology, 3(1), 36-49.

Ejimaji, E.U. \& Obilor, I. E. (2011). Assessment of Internet-Assisted Learning Resources (ILAR) in River State, Nigeria.Journal of Educational and Social Research, 1(5), 115-120.

Ekele, G. E. (2019).The marking of Agricultural Education: programme evaluation, competencies and theories. Makurdi: Selfers Press Ltd.

Federal Republic of Nigeria (2013). National policy of education. Abuja Nigeria: NERDC.

Iji, C. O. (2006). Information and Communication Technology ICT: A necessity for teachers and teacher education in Nigeria. International Journal of the Teachers Registration Council of Nigeria, 1(4) 26-34.

Nwana, S.E. (2010). Information and communication technology (ICT): A continuity in educational technology. Enugu: West \& Solomon Publishers.

Okeyefi,C.G.,\& Nzewi,C.(2012). Assessment of ICT competencies possessed by Biology Teachers in Nsukka Education Zone. In: O. Abonyi (ed), Meeting the challenges of UBE through STM education. Enugu: HEBN publishers.

Omoniyi, T. \& Ouadri, A.T. (2013). Perceived competence of Nigerian secondary school teachers in their use of information and communication technology (ICT). Journal of Educational and Practice, 4(10), 41-48.

Onasanya, S. A., Shehu, R. A., Ogunlade, O. O. \& Adefuye, O. (2011). Teacher's awareness and extent of utilization of information communication technologies for effective science and health education in Nigeria. Singapore Journal of Scientific Research, 1(2),49-58.

Surajo, A. M. R. \& Rislan, A. K. (2013). Integrating ICT to teaching and learning process in Nigeria: The pros and cons. Presented at $1^{\text {st }}$ International Conference of Arts \& Social Science at Sa'adatuRimi College of Education, Kumbotso, Kano, Nigeria.

Teo, T. (2008). Pre-service Teachers attitude towards computer use: A Singapore survey. Australasian Journal of Educational Technology, 24(4), 413-424.

UNESCO. (2009). Technical and vocational education and training for the twenty first century recommendations. Paris:UNESCO.

Yusuf, A.A (2007). Identification of ICT knowledge and skills in schools. Journal of computer Literacy, 2 (1), 25-31. 